\title{
Iowa's Civil War Marshal: A Lesson in Expedience
}

David L. Lendt

HERBERT M. HOXIE, IOWA'S U.S. marshal during the Civil War, is remembered, if at all, as a devoted public servant who performed his duty honestly and faithfully. ${ }^{1}$ Inasmuch as his tenure as U.S. marshal was not tainted by financial scandal, his career was distinguished from that of several of his predecessors. Some of his actions and activities, however, were arbitrary, unwarranted and, in all probability, unconstitutional.

He held office from May, 1861, to March, 1865. It was obviously not an easy time for the Union or for its marshals who were bound to enforce federal law in the states and territories. The emotions of the Civil War were as likely to affect a marshal as they were to excite any citizen. In addition, Hoxie's appointment was a political reward. A former editor of the Republican Des Moines State Register, he had also served as a member of the Republican State Central Committee. ${ }^{2} \mathrm{He}$ could hardly be an unbiased observer in the frenzy that followed the outbreak of national fratricide, and he was not.

As in virtually every military conflict, there were anti-war sentiments expressed during the Civil War and such sentiments were heard in Iowa, particularly in newspapers edited by Democrats opposed to President Lincoln's prosecution of the war. These Peace Democrats, as opposed to the War Democrats who sup-

'Philip D. Jordan, "The U.S. Marshal on Iowa's Frontier," The Palimpsest, LIV (March-April, 1973), 9.

${ }^{2}$ Frank L. Klement, "Rumors of Golden Circle Activity in Iowa During the Civil War Years," Annals of Iowa, 37 (Winter, 1965), 524; Klement, The Copperheads in the Middle West (Chicago: The University of Chicago Press, 1960), 19. 
ported Lincoln, were eventually referred to as Copperheads by their Republican critics.

The definition of the term, Copperhead, as the war progressed and as emotions took control, became continually less precise. It eventually was employed by Republicans whenever a scornful label, suggesting cowardice or treasonous activities, would be helpful in damaging the Peace Democrats and their exponents. ${ }^{3}$ In addition, the Republicans rolled out the spectre of the Knights of the Golden Circle (K.G.C.) whenever the Civil War citizenry went to the polls to select their governmental leaders. The K.G.C. was said to be a highly-organized, well-armed Copperhead organization whose professed aim was to overthrow the Union and establish a new, autonomous nation friendly to the Confederacy. ${ }^{4}$

In the approximately 110 years since the Republicans and their federal marshal, H. M. Hoxie, publicly warned of the dangers of the K.G.C. in Iowa, no evidence has been uncovered to substantiate their claims. Even so, the reports generated by Hoxie have been accorded the stature of fact by most Iowa historians and have even been repeated in recent historical data published by the State of Iowa. ${ }^{5}$

Among the newspapers published in Iowa during the Civil War, none can be found which could be defined as traitorous. Although several newspapers were outspoken in their criticism of Lincoln and his policies, in the tradition of the nation's free and unfettered press none espoused treason. Their editors viewed themselves as the loyal opposition and they limited their anti-war activities to the emotion-charged, and sometimes irrational, printed word and the ballot box. ${ }^{6}$

Some of Hoxie's actions in the heat of the political and military struggle in Iowa were at best ill-advised and heavy-handed, and at worst dishonest. They were detrimental to his objectives

3James Garfield Randall, Lincoln the President (New York: Dodd, Mead, 1945-1955), III, 187.

4Klement, "Rumors," 527 and 536.

${ }^{5}$ Robert Rutland, "The Copperheads of Iowa: A Re-Examination" Iowa Journal of History and Politics, 52 (January, 1954), 2; L. Dale Ahern, ed., Iowa Official Register (Des Moines: State of Iowa, 1969), 482. A special Civil War centennial report in this issue of the Register says of the K.G.C.: "Organized in many sections of the state, they were said to number 42,000 in all."

${ }^{6}$ David L. Lendt, Demise of the Democracy: The Copperhead Press in Iowa, 1856-1870 (Ames: Iowa State University Press, 1973), 135. 
and those of his political allies. The Copperheads in Iowa never enjoyed widespread support at the polls. No Iowa Copperhead was ever elected to Congress, and only a handful ever held seats in Iowa's General Assembly. Whatever public support the Peace Democrats were able to attract in the state, however, reached its peak as a reaction to the arbitrary and insolent policies of Marshal Hoxie and his colleagues.

Iowa was overwhelmingly Republican at the time the Civil War erupted and Iowans responded enthusiastically to the Union call to arms. Although the number has been mistakenly exaggerated, on a per capita basis, Iowa provided more fighting men to the cause of the Union than any other state.

President Lincoln determined early in the war that the privilege of the writ of habeas corpus could and should legally be suspended because, "I decided that we have a case of rebellion." 8 Because the Constitution forbade the Congress to suspend the writ except in cases of rebellion or invasion (and made no mention of the powers of the president in this matter), Lincoln's critics contended that only Congress could suspend it and that Lincoln acted outside the law in making such a decision unilaterally.

Early arbitrary arrests were largely overlooked, but the issue struck "home" in Iowa Christmas Day, 1861, when George Wallace Jones, the state's first U.S. senator, was arrested as a "southern sympathizer." Iowans were further dismayed when Gideon S. Bailey, who was the state's first U.S. marshal and a former territorial and state legislator from Van Buren County, was also imprisoned in a wave of arrests made to satisfy complaints from families of Union soldiers. ${ }^{9}$

In September, 1862, Lincoln proclaimed that, during the rebellion, persons discouraging enlistments, resisting the draft or guilty of disloyal practices were subject to martial law and trial by courts-martial or military commissions. Authority to suspend the writ of habeas corpus in such cases was also granted.

\footnotetext{
'Ahern, op. cit., p. 479. The Civil War centennial report in this issue of the Register states that more than 75,000 Iowans lost their lives in the Civil War. Approximately that number of Iowans served in the Union cause.

'Randall, Constitutional Problems Under Lincoln (Urbana: University of Illinois Press, 1951), 122.

${ }^{9}$ William J. Petersen, The Story of Iowa (New York: Lewis Historical Publishing Company, Inc., 1952), I, 440.
} 
Iowans were disquieted by the measure and Iowa Republicans felt obliged to justify their part in the widespread arrests. As the fall election campaign heated up, Marshal Hoxie apparently decided that the best way to deal with political opposition was through intimidation. Thus, despite an outpouring of editorials, addresses and resolutions on the part of midwestern Democrats, he made a sweep of arbitrary arrests in the fall of 1862 which netted Dennis Mahony, fiery editor of the Dubuque Herald and Iowa's most outspoken Peace Democrat, and Daniel Sheward, editor of the Fairfield Constitution and Union. ${ }^{10}$ The "fall roundup" also caught James Corban Taylor of Clarke County, Joseph K. and William Evans of Madison County and John Strohl, a farmer living near Centralia in Dubuque County. ${ }^{11}$

Hoxie's inability to justify the arrests to the satisfaction of Secretary of War Stanton caused the Marshal, and other Iowa Republicans, embarrassment when Stanton sent John Hay, as a special agent of the War Department, to investigate the situation in Iowa. In response to adverse public reaction, Hoxie blamed the phantom Knights of the Golden Circle for making his methods necessary. Governor Samuel Kirkwood claimed that K.G.C. lodges existed "in almost every county in the state" and that the Knights shipped ammunition to the South and gave aid and comfort to the Confederates. The governor warned that the K.G.C., with a membership estimated at 42,000 in Iowa alone, threatened the peace of the state.

The governor's information presumably came from Hoxie who, in September, 1862, warned Secretary of War Stanton that "powder and other articles of contraband of war were being transported from this State [Iowa] to Guerillas in Missouri." He charged that Knights were buying powder in small quantities "preparatory to striking a blow either in this State or Missouri." Noting that he had "deputies in all the border counties," Hoxie asked the Secretary's permission to prohibit the sale of powder without a permit issued by him or one of his deputies. He also insisted that the K.G.C. in Madison County "have arms and ammunition with which they intend to resist the execution of the laws of the United States" and asked whether he should disarm "those

${ }^{10}$ Klement, The Copperheads, 19.

"Klement, "Rumors," 527. 
that are known to belong to said lodges of the Knights of the Golden Circle?"

Stanton did not reply to Hoxie, but Major Levi Turner, associate judge advocate in charge of state prisoners, did. His instructions to Hoxie were to prohibit powder sales and to disarm suspected members of the K.G.C. if facts resulting from an investigation warranted such action. ${ }^{12}$ In a subsequent letter to Major Turner, Hoxie suggested that prisoners being held at Camp McClellan, the Davenport Recruiting Depot, would not be secure after November 15 [1862] because the recruits serving as guards were to be assigned to regiments on that date. "There are Eleven KGC's in the guard house at that Camp, and it is to those that I refer," Hoxie wrote. ${ }^{13}$

Although Iowa had successfully filled its quotas for military men in the nation's first exercise of military conscription, by November of 1862 the state's officials were having difficulty keeping the men it had signed up. Hoxie wrote to Turner, "I am called upon almost dailey [sic] to arrest deserters of company [sic] formed in the service of the State of Iowa . . . I mean men recruited by the State Recruiting officers to fill the Regiments called for by the President of the United States." ${ }^{14}$

How much the threat to Iowa's peace was a product of Hoxie's paranoia and his hyperactive imagination may never be known, but his accounts of impending conflicts which failed to materialize and his rendering of reports substantiated only by his vague personal impressions, smack of hyperbole and histrionics. Hoxie's letters to Turner were largely self-serving and their purpose, in most instances, was to enlarge Hoxie's authority. Certainly the most prolific U.S. marshal represented in Turner's collection of correspondence, Hoxie was inclined to beseech his superiors with lengthy pleas which they were inclined to answer with one-sentence telegraph messages.

Without substantiating his claims, Hoxie's reports to Wash-

${ }^{12}$ Letter, H. M. Hoxie to Edward Stanton, September 18, 1862. TurnerBaker Papers, National Archives and Records Service, Washington, D.C.; Letter, L. C. Turner to H. M. Hoxie, September 23, 1862, Turner-Baker Papers, National Archives and Records Service, Washington, D.C.

${ }^{13}$ Letter, H. M. Hoxie to L. C. Turner, October 31, 1862. Turner-Baker Papers, National Archives and Records Service, Washington, D.C.

${ }^{14}$ Letter, H. M. Hoxie to L. C. Turner, November 11, 1862. Turner-Baker Papers, National Archives and Records Service, Washington, D.C. 
ington gave the impression that the Iowa marshal was sitting on a powder keg about to be detonated by well-armed, wild-eyed traitors to the Union. In March, 1863, he wrote to Turner, "Governor Kirkwood has sent 50 muskets to Winterset and Capt. Hendersha [te] sent ten men back with Lieut. Henry. Lieut. H. informs me that several of the leading Copperheads have left the county. I think now that if the leaders are disarmed that no trouble will ensue." In the same letter, he reported, "In my own town [Des Moines] the 'Copperheads' threatened very strongly to take some deserters out of my hand[s]. I immediately removed the prisoners, and peace was restored very soon. I now have about 30 muskets and hope to maintain order." 15

The suspicious Hoxie saw violent Copperhead revolution brewing on all sides. In April, 1863, he wrote Turner, "A Copperhead firm of this city [Des Moines] has, I am informed, ordered 100 Navy revolvers, and I am satisfied that there is no necessity for so large a number at this time, except it be to arm disloyal men. The same firm has now a large number on hand. They sell to disloyal men. I am also satisfied that other firms are doing the same business, as I have been applied to in the last few days for permits to ship munitions of war to this place. I have refused to give the same." ${ }^{16}$

Arbitrary arrests were made a major issue in the 1862 elections throughout the Midwest. The critics of the Lincoln administration added to the president's embarrassment by staging heroes' welcomes for political prisoners freed soon after the votes had been counted and the Democrats had made substantial gains in the U.S. House of Representatives. The Dubuque welcome for Mahony, "honorary discharged" from the Old Capitol Prison in Washington, D.C., November 11, was described by the Republican editor of the Dubuque Times as a "most preposterous, treasonable, and disgraceful exhibition." 17

Iowa Copperhead leaders, in general, were well-educated and sincere critics of the Lincoln administration, although they were

${ }^{15}$ Letter, H. M. Hoxie to L. C. Turner, March 7, 1863. Turner-Baker Papers, National Archives and Records Service, Washington, D.C.

${ }^{16}$ Letter, H. M. Hoxie to L. C. Turner, April 11 (?), 1863. Turner-Baker Papers, National Archives and Records Service, Washington, D.C.

${ }^{17}$ Quoted in Klement, The Copperheads, 23. 


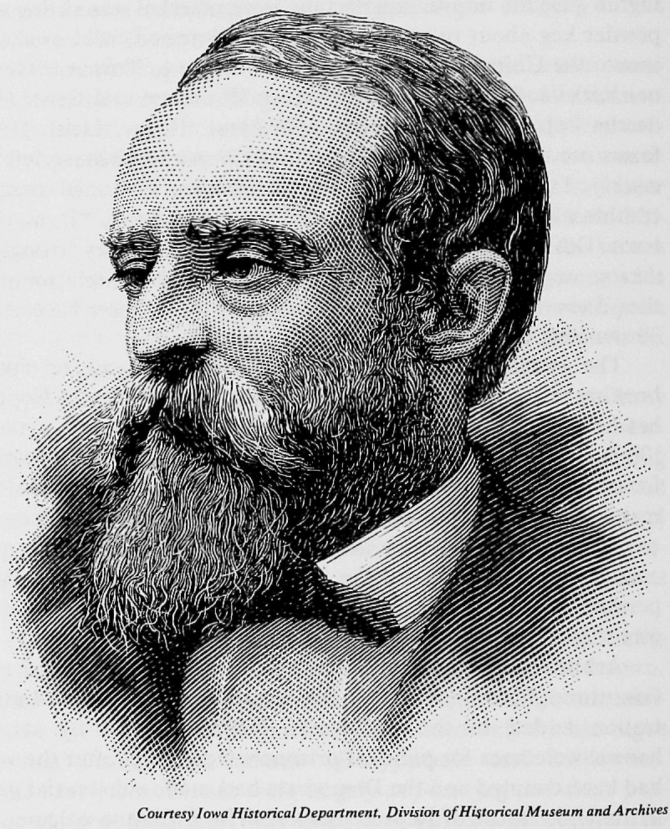

Herbert M. Hoxie

painfully out of touch with the profound social and political changes pervading the bloody national conflict. They were fiercely conservative in a state which had long before set its course on social justice and whose citizens were generally committed to abolition of slavery. As a political force, the Copperheads in Iowa were virtually impotent, but the issue of arbitrary arrests and the plight of the Union Army in the field had helped to fashion a growing block of resistance to the Lincoln administration in Iowa and throughout the Midwest. The downfall of the Copperheads in 
Iowa can be traced not to Hoxie's "watchful eye" or his zealous expedience, but to events on a national level. The Copperhead star was in its ascent in Iowa when the fortunes of war and, with them, the heart of the body politic, turned irreconcilably in favor of the Union. With the defeat of Lee at Gettysburg, dispirited northerners resolved to "back a winner" and see the war to its predictable conclusion.

Marshal Hoxie may have done his job "faithfully and well" according to his Radical Republican contemporaries. From the vantage point afforded by a century of retrospect, however, he did a disservice to Iowa. By polluting its stream of history with rumors and untruths, given the stamp of approval by the state's Republican administration, he misguided and violated the rights of his contemporaries and misled generations of Iowans who followed them.

Portrait of Iowa, by Paul Engle, with photographs by John Zielinski and others (Adams Press, 59 Seymour Ave., S.E., Minneapolis, Minnesota 55414) is a pleasing pictorial survey of contemporary Iowa. Zielinski's many photographs of the Amish, living in a 19th century mode essentially set apart from mainstream America, make a poignant statement about beauty in simplicity. The Amish photographs dominate this book, somewhat over-emphasizing the sect's importance in the state.

Engle's text summarizes Iowa's midwestern characteristics, the stabilizing factors that have shaped its past: a central location in America's heartland, rich farmlands, extremes in weather, varied topography, and diverse population groups. Portrait of Iowa is a handsome showpiece, and sells for $\$ 14.95$. 
Copyright of Annals of Iowa is the property of State of Iowa, by \& through the State Historical Society of Iowa and its content may not be copied or emailed to multiple sites or posted to a listserv without the copyright holder's express written permission. However, users may print, download, or email articles for individual use. 